\title{
THE MUSLIM PRECARIAT OF ASSAM: CONTAGION, MIGRANTS, AND COVID-19
}

\author{
Yasmin SAIKIA
}

COBISS 1.02

\begin{abstract}
The Muslim Precariat of Assam: Contagion, Migrants, and COVID-19

This article examines the plight of migrant Muslim garbage pickers during the COVID-19 lockdown in India and their struggles to return home to Assam. Their financial hardships were exacerbated by social, political, and religious prejudices. Belonging to the Bengali-speaking miya community, deemed "Bangladeshi," government authorities neglected them. The lockdown's hyped-up anti-Muslim propaganda also reduced them to "corona jihadis." The author reads their struggles as a case study of the Muslim condition in India and argues for civic engagement for redressing the condition of the marginal and vulnerable. The research was conducted through telephone and Zoom calls and in-person interviews.

KEYWORDS: Assam migrants, COVID-19, lockdown, miyas, Muslim precariat, India
\end{abstract}

\section{IZVLEČEK}

\section{Muslimanski prekariat v Assamu: Okužbe, migranti in Covid-19}

Članek obravnava stiske migrantskih muslimanskih smetarjev med popolnim zaprtjem javnega življenja v Indiji in njihova prizadevanja za vrnitev v rodno pokrajino Assam. Družbeni, politični in verski predsodki so njihove finančne težave še povečali. Zaradi njihove pripadnosti bengalsko govoreči skupnosti miya, ki izvira iz Bangladeša, se indijske oblasti zanje niso menile, okrepljena protimuslimanska propaganda jih je v času lockdowna obravnavala kot »korona džihadiste«. Avtorica njihov boj za preživetje obravnava v okviru splošnega položaja muslimanov v Indiji, obenem pa se zavzema, da bi civilna družba naredila več za izboljšanje položaja najbolj marginaliziranih in ranljivih skupin. Raziskava je bila izvedena po telefonu, aplikaciji Zoom in z osebnimi intervjuji.

KLJUČNE BESEDE: migranti iz Assama, Covid-19, zaprtje, skupnost miya, muslimanski prekariat, Indija

PhD in history, Arizona State University; ysaikia@asu.edu, https://orcid.org/0000-0002-4321-1188. 


\section{INTRODUCTION}

Map 1: Map of Assam State and Northeast India (made by Eric Friesenhahn at the Map and Geospatial Hub, Arizona State University Library).

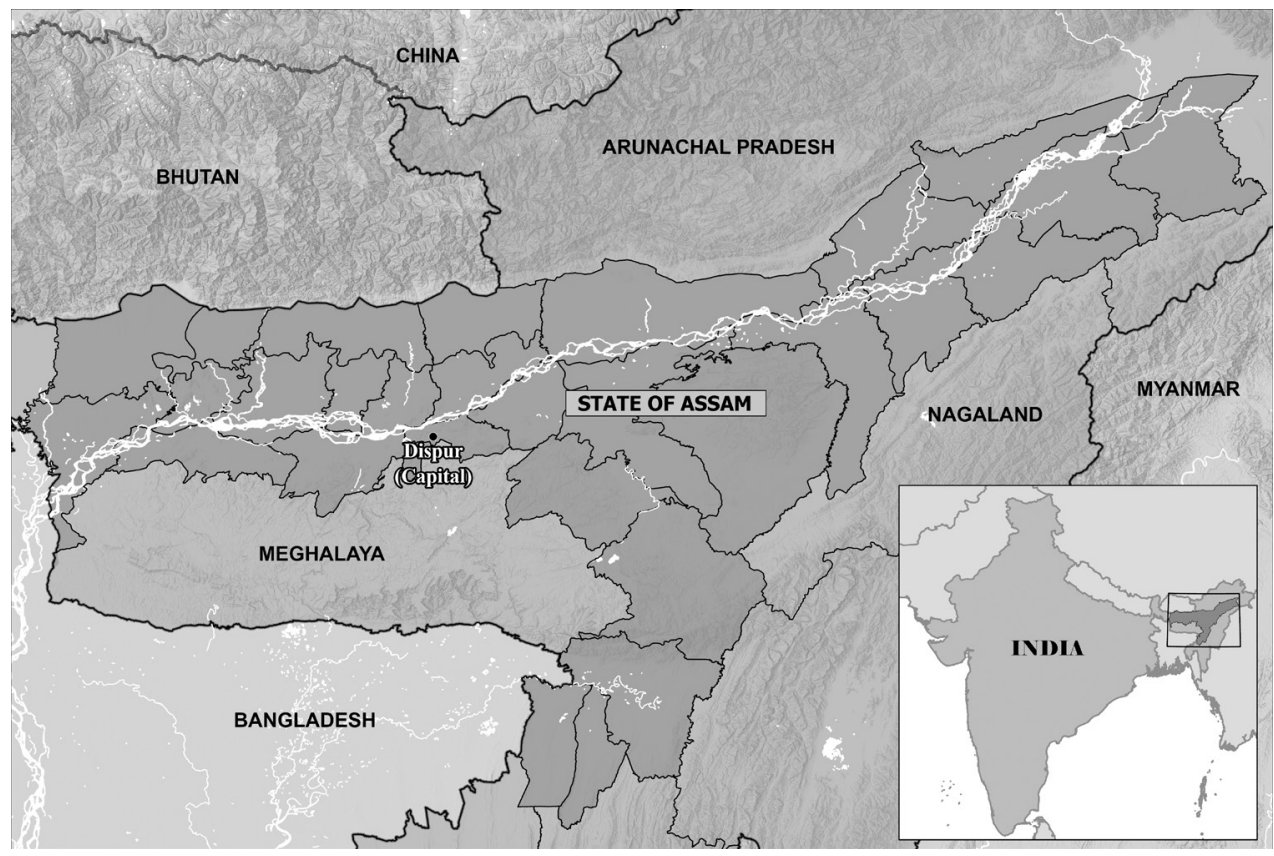

"Last night [April 4], the police arrested two terrorists hiding in the Kasimpur mosque who had returned from the Jamaat meeting. We live in fear of the Muslims; they have grabbed our land, and now they are spreading the contagious coronavirus. They are corona terrorists." Taxi driver Rabha continued his rant against the Muslims as we walked along the meandering hillside of Kharguli, in Guwahati, Assam, one of the seven states constituting northeast India. Rabha's account of the jamaati covidterrorists in our neighborhood reiterates the weaponized story constructed and circulated by the Bharatiya Janata Party (BJP) government that rules India based on the religious ideology of Hindutva or Hindu nationalism (Jaffrelot 2007). According to the government, the Muslim organization Tablighi Jamaat, which convened a meeting in Delhi on March 8-10, 2020, spread the virus in India (Ellis-Petersen, Rahman 2020). Thus, the pernicious narrative of COVID-19 as a Muslim contagion instigated the public against Muslims.

On March 25, 2020, prime minister Narendra Modi locked down India for twentyone days to contain the spread of COVID-19. Multiple lockdowns followed for three months until late June. Lockdowns in India are a form of punishable collective incarceration. In Assam, there were no COVID-19 cases when the first lockdown was announced. Nonetheless, the entire state ceased all activities, and movement outside 
one's home was prohibited. Giving substance to the government's fictitious narrative of Muslims as carriers of the coronavirus, the local media published the names of various Muslim "super spreaders," the two men of Rabha's story among them. However, these men were neither Tablighi Jamaat members nor bioterrorists; they were businessmen returning from Bangalore to Manipur (another state in the northeast). Stranded in Guwahati and without funds to pay for a hotel room, they received shelter from a local Muslim organization. However, being Muslims, they became suspected "corona-jihadis" and were arrested on charges of the intent to spread the novel coronavirus.

Like the SARS-CoV-2 virus, Muslims are viewed in Assam as outsiders, infiltrators destroying the culture and identity of the Assamese Hindu community. The community derogatorily referred to as "Bangladeshi" or miya are also debased as gedha or filthy. ${ }^{1}$ This article highlights the struggle for survival of two miya communities stranded in northern India - Kanpur in Uttar Pradesh and Gurgaon in Haryana - during the nationwide lockdown. These two groups are among the many migrant miya communities employed in the informal sector outside Assam, performing what others consider gedha or filthy work. They are among the poorest of the poor, even lower than the Dalit groups in India, landless, illiterate, often unemployed as well as threatened with expulsion from Assam and India because they are deemed Bangladeshi.

The miyas' "bare lives" (Agamben 1998) are bodies for political oppression. Viewed as illegal immigrants in Assam, they are threatened with denationalization by the National Register of Citizens (NRC), compiled in August 2019 to detect the "illegals." Although the vast majority have been able to prove their Indian citizenship, miyas remain an outcast, pariah community denounced by the government and the mainstream public. Their treatment during the lockdown reveals the inequality of human lives in India, the world's largest "democracy," which is only "partly free," according to the latest Freedom House Report. ${ }^{2}$

Drawing upon Guy Standing's term "precariat" (2011), I present the miya garbage pickers as a "Muslim precariat," though not dangerous and alienated like Standing's precariat in the West. Following Levinas ([1974] 1998), I see each human life as valuable. The Muslim precariat does the dirtiest work in the hope of transforming their seemingly worthless existence into something of value, a testimony to a continuous human struggle for acceptance and the right to live in dignity. They hope for a better life for their children who can belong to the national community. Hard work, resilience, and the capacity to dream highlight the dignity of their work and their humanity.

\footnotetext{
1 Recently, the community adopted the term miya as a resistance against the humiliation and indignity they suffer. I am using the term in the same spirit in this article.

2 For details, see https://freedomhouse.org/country/india/freedom-world/2021.
} 


\section{METHODOLOGY}

Adopting a methodology incorporating history and ethics, I develop the concept of the valued humanity of miya garbage pickers by exploring their experiences during and after the COVID-19 lockdown. For developing this methodology, I draw upon historians of the Holocaust, such as Hannah Arendt, Giorgio Agamben, and Inga Clendinnen, among others, and the ethical philosophy of reciprocity in Islam, as well as the scholarship of Emmanuel Levinas and Maurice Blanchot. ${ }^{3}$ Specifically, I explore the experiences of those who migrated back home to Assam and the ones who could not. What motivated the returnees, and how did they organize their long journey back? Why could some of them not leave? What made the experience of the Gurgaon migrant workers different from the ones in Kanpur? Taking a longue durée view, I frame the stories of the Gurgaon and Kanpur garbage pickers during the lockdown against the history of their initial movement from Assam in search of jobs and their experiences of returning home during the pandemic.

I approach the study of the garbage pickers' lives as a site for creating value from abandonment. Filth and cleaning are two sides of their lives. Grinding poverty, illiteracy, landlessness, bureaucratic neglect, and political dispossession mark these people in normal and abnormal times. They survive/d in the "zone of non-being" (Fanon 2008), defeating a system that makes them disposable. These lives are bound up with the lives of others, as they clean up spaces that all inhabit, urging us to rethink the experience of COVID-19, lockdown, and migration in anticipation of a better tomorrow.

Due to restrictions on movement during the lockdown, research was conducted through telephone interviews. I conducted three phone interviews with three managers, which totaled nine interviews. Each interview ranged between one to two hours. Additionally, I did several Zoom and telephone calls with facilitators in Gurgaon and Bangalore and met with local facilitators in Guwahati, Assam. Since I was in Guwahati during the COVID-19 outbreak and the initial lockdown, I visited some quarantine facilities to gather a first-hand impression of the arrangements. There, I met with government officials, NGO workers, and journalists who were aiding the returnees. The information gathered from various interlocutors appears in quotes in the text and is cited in the footnotes.

\section{Living in Garbage: The Inhuman Lives of Humans}

Miya garbage pickers lead abject lives even in normal times, but during the COVID-19 pandemic, it became unbearable. The pickers live in dump yards, usually under busy

3 The topic of reciprocity in Islam is a well-studied area and has many local and cultural expressions. In Afghanistan it works as Pakhtunwali, in Arabic speaking countries diyafa or hospitality is sacrosanct, in the Indian subcontinent the culture of mehman nawazi is the mark of civility and refinement, and so on. Extensive bibliographies on related concepts are available in Siddiqui (2015) and Parrott (2018). 
flyovers, rented by a sardar or labor manager. Each family pays rent for a house made of plastic sheets for walls and scrap tin for a roof. They share common toilets that do not have running water, and there is very little privacy among the families. The living compounds also serve as workspaces where the pickers initially sort the garbage, clean, and pack the waste. The packed garbage is sent to recycling companies within the city or outside. According to Anwar Rahman, one of the managers of the Gurgaon garbage compound, some of the packed garbage is sent to Rajasthan and Uttarakhand in North India, besides Delhi. ${ }^{4}$ In Kanpur, Aminul, who manages the compound there, told me that he sells most of the garbage locally. ${ }^{5}$ The Gurgaon compound, managed by Jiaur Rahman and Anwar Rahman, houses more than 500 pickers, and they manage two additional compounds in Gurgaon, totaling about 2,000 pickers under their care. ${ }^{6}$ The Kanpur compound managed by Aminul has 180 garbage pickers. Survival for the managers and the pickers depends on the income generated from the garbage collection. On my inquiring why they cannot do the same work in Assam, they responded that, while a few small groups in Guwahati do this work, there is very little garbage to collect. Anwar explained: "Since Assam does not have a large industrial base, the production of goods and consumption are both low, and it is not profitable to collect garbage for recycling and generating income." The lack of work in Assam, even something as rudimentary as garbage picking, forces the unemployed miyas to migrate out of this state for a livelihood.

Garbage pickers are between the ages of thirteen to fifty years. The life span of the workers is low, but the duration of their work life is very long. Most garbage pickers are illiterate or have minimum education. Anwar and Aminul, however, are somewhat educated; Anwar studied law but quit due to financial problems, and Aminul completed high school. The pickers earn an average monthly income of 10,000 Indian rupees (less than 150 US dollars) in both Gurgaon and Kanpur. "This is a considerable amount of money for people who had no income in Assam and barely managed to eat a square meal every day," stated Jiaur. He elaborated, "Because of work, they can afford food and accommodation, and even save and send money home to their families [...] They are hard-working, productive workers."

Cleaning the mess of others is not an easy job. Instead of appreciation, the Gurgaon pickers are often threatened with eviction, and they face hostility as Muslims. Jiaur has forbidden his workers to wear their native clothes, which sets them apart from the local Gujjar Hindus in Gurgaon. Also, they have consciously decided not to speak Bangla or Assamese (their native languages) outside the compound, only Hindi. Both Jiaur and Aminul communicated with me in fluent Hindi. Anwar, on the other hand, took pride that he could speak fluent Assamese.

4 Phone interview on 23 Jan. 2021. Anwar Rahman also shared several videos of workers' everyday life in the dump yards and their journey to Assam.

5 Phone interview on 15 and 17 Jan. 2021.

6 Phone interviews on 23 Jan. 2021. 
Nonetheless, their efforts to mingle and merge with the local people in Gurgaon and Kanpur have proved inconsequential. During the COVID-19 pandemic, none of their neighbors came to their rescue. "We keep their neighborhoods clean, yet our lives have no value to the people whose filth we are taking care of," Jiaur recalled.

The routine violence extends to the lives of their children, who are forced into labor from an early age because of the lack of schooling. Although the Gurgaon pickers have access to primary education inside the compound, only two children attend middle school outside. One of them is Jiaur's son. In Kanpur, on the other hand, the landowners have forbidden Aminul from constructing a school inside the compound. Consequently, the garbage pickers' children in Kanpur are deprived of education. Although they can attend school outside, "they are shunned by the other students, and they are embarrassed," according to Aminul. The lack of education of these children is one of the main concerns of Jiaur, Anwar, and Aminul because "if they have education, their valueless lives will have value," Aminul told me.

Another problem is the lack of space for performing religious duties and daily prayers as Muslims, the religion of most garbage pickers, including those from West Bengal and Bihar. "Of the ten thousand garbage pickers, nearly seventy-five percent of them in Gurgaon are Muslim," according to Jiaur. But they are not allowed to observe daily congregational prayers inside the garbage compounds. In Haryana, the BJP government destroyed several mosques, and no prayer is allowed in open spaces or public parks, which restricts the Muslim religious duty of daily prayers. Community prayer cannot be observed except on Friday, for which Jiaur received permission from his landowner to use the schoolroom inside the compound as a mosque. Even so, the prayers are conducted almost in secrecy.

The boundary of municipal services excludes their compounds, so there are no public amenities. During the lockdown, the workers had to live without income and government support. The lack of food and water and the problem of summer heat were compounded by the uncertainty of the duration of the lockdown, COVID-19, and its impact. This situation caused great anxiety, and the workers were desperate to return to their villages, but their hopeless condition was not initially evident to the authorities. They are the unrepresentable, excluded from the fantasy of "shining" India. This group of forgotten and abandoned miyas is one among the many marginalized Muslim communities in the BJP's India whose lives are valueless and their deaths ungrievable (Butler 2020).

\section{Visible and Invisible Migrants from Assam}

The northeast Indian states of Assam, Manipur, Meghalaya, Tripura, Mizoram, Nagaland, and Sikkim comprise a large part of India's migratory workforce because of factors such as militancy, lack of a manufacturing sector, big business and trade, environmental changes, and limited employment in public and private sectors (Xaxa 
et al. 2019). The "Look East" policy launched by the government failed to produce real results, and employment and the economy are not expanding in the region. The oil, gas, and tea industries in Assam absorb only a small percentage of the available labor force. "In Assam, there is more labor than the opportunity to work," as Anwar astutely summed up the situation. The Hindu high-caste communities have a relatively higher level of employment in the government sector. In contrast, the share of workers engaged in the unorganized sector is increasing for the religious minorities, particularly Muslims. The unemployment rate in the northeast is much higher than the national average, and studies predict it will increase, particularly among the religious minorities and hill communities (Tripathi 2016; Khongji, Nongkynrih 2018).

There are two kinds of migrations of the people out of northeast India. ${ }^{7}$ One is internal migration within the region for employment in agriculture, housework, and manual labor. The second and more obvious migration is to other parts of India. The longest corridor of migration from Assam is to Kerala in southern India. Large numbers of Muslims from flood-wrecked miya communities who have lost land to erosion and/or did not own agricultural land and are illiterate have migrated to Kerala, Karnataka, Andhra Pradesh, and Tamil Nadu to work in various industries such as plywood manufacture, fishing, and boating and as garbage pickers and workers on coffee and tea plantations. There is no official report of the number of miya workers outside Assam, but Anwar estimated more than 500,000 work in the informal sector. Of these, more than 100,000 are garbage pickers.

The first wave of migration from Assam started in the 1990s due to the rise of militancy after the failure of the Assam Agitation (1979-1985), a local ethno-religious identity movement aimed at driving out non-Assamese and "Bangladeshi outsiders"; and the violent Bodoland movement, a breakaway group from Assam, which targeted the miyas in their area. Throughout the early 2000s, the pace of migration from Assam increased. The presence of "visible migrants" - educated Assamese generally employed as software engineers, IT personnel, lawyers, and journalists; and semi-educated Assamese migrants in the service-sector businesses of food and beverage, hotels and spas, security, salons, beauty, wellness, and nursing - became pronounced during the COVID-19 outbreak. Northeasterners have Mongoloid features, which instigates racial hostility. Pejorative terms such as "chinky" and "jungly" (uncivilized) are commonly used to demean them (McDuie-Ra 2012). During the COVID-19 outbreak, they were targeted with violence as "Chinese" and "Covid carriers" after Donald Trump carelessly declared COVID-19 to be a "Chinese virus" (Hoakip 2020). For Muslims, the added accusation of corona jihadi made them extremely vulnerable, staying inside their houses, locked up for days in fear of reprisal.

7 For further reading on the patterns of migration within and outside northeast India, see Lusome and Bhagat (2020). 
MAP 2: Four districts in western Assam with highest out-migration of miya garbage pickers (made by Eric Friesenhahn at the Map and Geospatial Hub, Arizona State University Library).

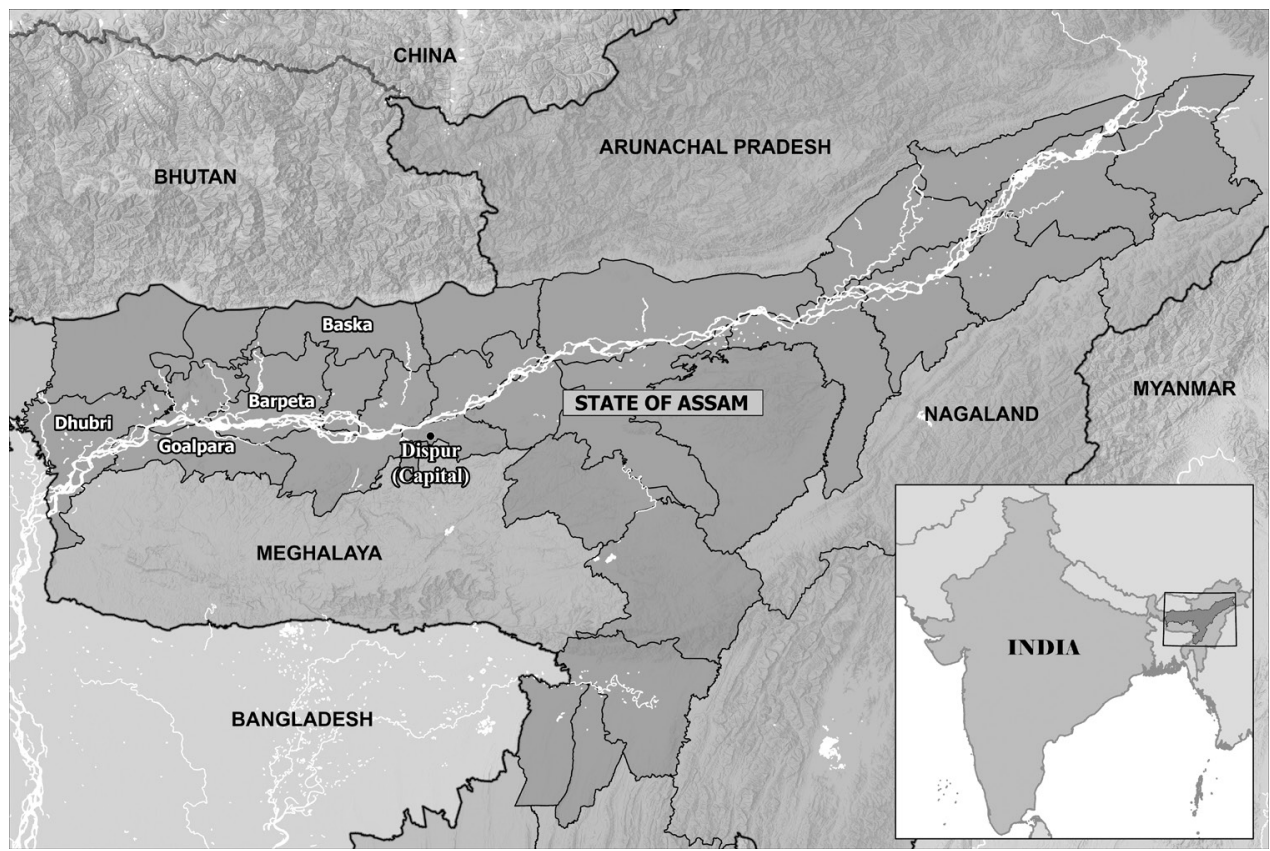

The "invisible migrants" - illiterate miyas who have migrated out of Assam due to communal violence, landlessness, and poverty - hail mostly from Dhubri, Goalpara, Barpeta, all economically depressed Muslim majority areas in western Assam; and from the Bodoland Territory of Baksa where miya families were victims of communal violence (Chakrabarti, Longkumer 2020). Hence, leaving Assam for work is a necessity, a path to escape violence. Most of these workers have found employment outside Assam through their local networks of family and friends in Uttar Pradesh, Delhi, Haryana, Karnataka, and Maharashtra and work in the informal sector as rickshaw pullers, daily laborers, garbage pickers, fruit and vegetable vendors, and drivers. Until COVID-19 ravaged their lives, they were unaccounted for as productive labor.

Irrespective of religion and status, workers from Assam stranded outside their homeland faced hostility, extreme uncertainty, and heightened fears and anxiety during the pandemic. The fear of dying far away from home amplified the desire to return home. Many believed they would return to Assam and find work there, but few have. Once again, financial circumstances and unemployment compel them to return to their workplaces in other parts of India. 


\section{Whose Lives Count? The Struggle to Reach Home}

During the initial lockdown, millions of migrant laborers and their families who were abandoned by their employers in India's cities, desperate, fearful, and penniless, tried to return to their native villages where they hoped their family networks would help them survive. Many died along the way, crushed by trains; some were run over by trucks; others died of sheer exhaustion. According to media reports, the movement of the workers became the biggest migration of human beings since the partition of India and Pakistan in 1947. The government addressed this human crisis by interdicting people's movement outside their homes. Police surveilled and punished the offenders.

The garbage pickers from Assam recall that, unlike the other migrants who, after a month of lockdown, defied the restrictions and started walking home, they could not. Assam is over one thousand miles from Gurgaon and Kanpur. The Gurgaon workers, being in proximity to Delhi, were better informed than the more remote Kanpur workers, yet both "did not step outside their compounds ... for over a month," both Aminul and Jiaur recalled. As vulnerable Muslims living in Uttar Pradesh, which is ruled by the hardcore BJP chief minister Yogi Adityanath, the Kanpur garbage pickers had fewer opportunities to return home. The work of garbage picking had come to a grinding halt, so there was no income. Inside the compounds, because the accumulating filth could not be disposed of, people lived next to piling garbage. The sweltering summer heat made their precarious plastic-sheet houses unbearable. But they sat day after day in this horrific condition without anyone taking notice. In desperation, Jiaur and Anwar in Gurgaon decided to act. A video they posted on Facebook drew the attention of several concerned citizens and helped others to reach them. NGOs provided them with weekly food rations and water, and slowly, plans for their migration to Assam started to take shape.

Nationally, more than a month after the first lockdown, facing intense criticism for neglecting displaced workers in the cities, the government launched a new scheme: the Migrant Workers Return Registration. The aim was to count the number of migrant workers stranded outside their home states, arrange their transportation, and ensure fourteen days of quarantine facilities after they reached their hometowns. State governments across the country launched online portals to register the migrant workers who wanted to return home. Buses and Shramik (workers) special trains were arranged to transport the migrants. While, on paper, the government's actions appeared planned and organized, the migrants from the northeast encountered a variety of problems, including misinformation, poor communication, lack of coordination, and uncertainty of transportation; those who journeyed back on trains, buses, trucks, and even ambulances suffered immensely. Their journey back home was fraught with problems from the lack of food and water and attacks from other migrants who were walking back home; some contracted the virus from infected travelers and died without medical attention (Haksar 2020). In May, after the first lockdown, there were over 600,000 workers stranded outside Assam. 
Based on my discussions with volunteers who facilitated the movement of migrants, one of the biggest challenges for the illiterate miya garbage pickers was the lack of money and information. Most of them did not have a bank account and could not avail the government support of 2,000 Indian rupees (less than 30 US dollars). Advocates Atifur Rahman and Aman Wadud from Assam and Anirban Gongopadhyay, a concerned citizen from Gurgaon, who saw the garbage pickers' video on Facebook, ${ }^{8}$ arranged for food support, water, and transportation home by buses and Shramik trains; one group availed a flight from Delhi to Guwahati. They successfully sent home nearly all the migrant workers from the Gurgaon enclave after three months of the initial lockdown. However, the garbage pickers at Kanpur had minimal help, and few could return home, according to Aminul. Only twenty-five of the one hundred eighty people in his compound took the train home; seven went by an ambulance that he arranged. The rest remained stranded in the garbage-filled compound. With the miyas surviving on donations from Muslim organizations and after a month withoun t income, Aminul was able to procure letters from recycling companies willing to buy their garbage and police permission to resume work. He stayed in Kanpur throughout the lockdown to assist his workers. It was also the month of Ramadan, and their psychological anxiety and extreme pecuniary condition were a test of faith and the capacity to endure.

As college teacher Rehana Sultana told me, forty miya workers from Murshidabad in western Bengal were abandoned by their manager during the lockdown. ${ }^{9}$ Having no recourse, they decided to walk home. They survived on a diet of biscuits and water for three days until they arrived at Siliguri on the border of Assam and West Bengal and availed a bus ride to their village. Similarly, another group from Bangalore (in Karnataka), unable to take the Shramik train due to incorrect information, decided to walk. This impossible journey was nearly 1,600 miles; so, compelled to hire a bus and assisted by Rehana, they reached Guwahati after four days of surviving on the bare minimum of food. The bus ride cost them over 100,000 Indian rupees (1,300 US dollars), almost all their savings. Why did they endure such pain to return to Assam? "We wanted to return home." A curious uneasiness lurks in this claim - for miyas, Assam is home, yet the Assamese consider miyas as outsiders. This haunting problem will exceed the anxiety of COVID-19 and its aftermath.

The miya migrants working within Assam also faced hardships to return to their home villages. Rehana recalls that getting permission for their movement was mired in obstacles. The government did not arrange for their transportation, so the majority walked home for several days. Along the way, they were harassed by the local authorities and the police because "in their eyes, they are viewed as Bangladeshi," Rehana commented.

8 I conducted phone interviews with Rahman and Gongopadhyay on 30 Dec. 2020 and 17 Jan. 2021. 
The miya migrants returning from outside Assam, like all other groups of returnees, were quarantined in different facilities, another test of their endurance. On arrival in Assam, almost all of them were initially neglected, with no information, assistance, food, or facilities. They waited for several hours in limbo before they were bused to the quarantine centers in local schools, far from Guwahati, the capital city. In these centers, after rapid testing, thirty to thirty-five men were packed into a single room without adequate toilet facilities. After fourteen days of quarantine, the workers staged a protest for their release. Due to the lack of facilities to house so many returnees, the government finally allowed most of the returnees to quarantine at home. ${ }^{10}$

The returnees faced acute financial problems at home since their extended stay without work had depleted their limited savings. Borrowing money at high interest rates is now one of the biggest problems facing these families, according to advocate Atifur Rahman. Without the financial support of the migrants, their extended families are also in a critical state. Their financial problems are aggravated by floods, which have destroyed their precious crops and have displaced many. ${ }^{11}$ Death, even by suicide, became common, according to advocate Rahman.

The returnees who are not verified in the NRC as citizens are in even worse psychological condition. Musa Mandal is one among many of these helpless people. Musa is a daily wage laborer, an internal migrant; during the lockdown, he had no work, so he returned to his village. During the initial NRC registration process in 2015, being illiterate, he could not complete the forms to prove his citizenship. Although during the lockdown period the courts had ceased to work, once the restrictions were eased, the Foreigners Tribunal (FT), charged with the task of verifying the citizenship of the miyas, immediately resumed its work. Musa Mandal, being unable to produce the citizenship verification papers, committed suicide on October 11, 2020. According to Atifur Rahman, since there was no oversight of the work conducted by the FT during the lockdown, many miyas were randomly removed from the citizens' register. In the meantime, some of the detained miyas were released from detention centers, ${ }^{12}$ with no work to help survive during the lockdown. On the other hand, new arrests of miyas continued.

The Border Police can arrest anyone suspected who is deemed an illegal citizen under suspicion of being a "doubtful" voter. The "D voter" category was created in 1998 after the government decided that the Bengali Muslims in Assam are not genuine citizens. The $D$ voters can be detained and expelled from India if they fail

10 Information about the hardships in the quarantine centers were provided by Anwar, Anirban, and Rehana.

11 Mirza Lutfur Rahman has documented the displacement of the families due to floods in several videos. Rahman supported by research in multiple ways for which I am deeply grateful. Chakrabarti and Longkumer (2020) also conducted interviews and produced a video and an article on the flood's effects.

12 See Rahman's video (2020a). 
to prove their status as citizens. "Life became a nightmare for the D voters during the lockdown," Atifur explains. Invoking Article 14 of the Indian Constitution, which ensures rights to citizens, corporations, and foreigners, for now, Atifur has managed to provide immediate provisional relief to the migrant workers, such as governmentsponsored health care, train tickets for their return to Assam, and small amounts of monetary support. However, he is fully aware and deeply concerned that the miyas flagged by the FT will ultimately be declared foreigners. He believes they will be sent to detention centers and that "they will die there. They are not Bangladeshi, and the government of Bangladesh will not accept them," he mused about the future of the miyas in Assam. "The lives of the unverified miyas have become meaningless in these circumstances, and suicide will be on the rise," Atifur fearfully predicts.

We should all be outraged by this extreme violence against the marginal and vulnerable. In Assam, however, politicians have convinced the public that driving out the illegal miyas will result in a secure homogenous Assamese community and that "true" Assamese will have ownership of the state and its culture. Unfortunately, many support this outcome. Miya is the political issue that overrides human ethics for the Assamese.

\section{CONCLUSION}

The precarity of miya lives before, during, and after the multiple lockdowns in India raises questions about our responsibility to those of us who, daily, live the horror of being valueless. I have focused on the lives of the garbage pickers to highlight this issue: we depend on their labor for our comfort and public health, yet we willfully overlook that their lives matter.

The public in India can enjoy urban spaces such as parks, unclogged public drains, and unlittered roads because of garbage pickers. Yet, the people doing this labor are invisible. The relation of interdependency should be obvious, but the social and political structures that produce the inhuman lives of the precariat numb us. We do not like to see garbage: we want it removed from our view. In the process, we also clean out and erase the people who do the work we demand.

The lack of value for miyas' work and, consequently, public indifference to their inhuman condition raise a fundamental question of who is visible and dignified and who is not. The garbage pickers are proof of the unequal visibility of human lives in economically developing India, pushed by international corporations and Western countries into reckless growth. The capital development moving the nation forward, however, casts large groups of people aside, like garbage.

What does not appear to be a life, however, is a human life. To bring it to visibility, as Anirban Gongopadhyay says, "We have to stop living in the cocoon that we do... to see people who live near us, but with whom we do not build a relationship." Crossing the threshold of routine indifference, as Anirban did, reaching out to the garbage 
pickers, opened the space and created the possibility of "becoming useful to someone else."

Every act during the lockdown that broke the violence against the invisible reaffirmed the living humanity of the unseen and neglected. These small recognitions of the other during the COVID-19 pandemic and lockdowns limited and resisted persistent exclusion and brought into view their lived human world. Enabling the survival of these human lives is the beginning of building an interdependent relationship, which can be complicated, even unstable, but it is a beginning, no doubt. "In recognizing the need of the other, I was doing myself a favor. I was able to do something, become active despite the orders to be inactive during the lockdown," Anirban summed up. The dignity of interdependent humans is not political but ethical because contagious humanity survives beyond the deathly grip of the virus. It must.

\section{REFERENCES}

Agamben, Giorgio (1998). Homo Sacer: Sovereign Power and Bare Life. Palo Alto, CA: Stanford University Press.

Butler, Judith (2020). The Force of Non-Violence. London: Verso.

Chakrabarti, Angana, Longkumer, Yimkumla (2020). Jobless in Villages amid Floods Assam's Returning Migrants Brace for Fight to Stay Afloat. The Print, 3 July, https:// theprint.in/india/jobless-in-villages-amid-floods-assams-returning-migrantsbrace-for-fight-to-stay-afloat/452403/ (2 Mar. 2021).

Ellis Petersen, Hannah, Rahman, Shaikh Azizur (2020). Coronavirus Conspiracy Theories Targeting Muslims Spread in India. The Guardian, 13 Apr, https://www. theguardian.com/world/2020/apr/13/coronavirus-conspiracy-theories-targeting-muslims-spread-in-india (2 Mar. 2021).

Fanon, Frantz (2008). Black Skin, White Masks. New York: Grove Books. Original publication: 1952. Peau noire, masques blancs. Paris: Éditions du Seuil.

Haksar, Nandita (2020). Filthy Toilets, Attacked with Stones: For North East Workers from Goa, a 119-Hour Nightmare on Rails." Scroll.in, 27 May, https://scroll.in/article/963011/filthy-toilets-attacked-with-stones-north-east-workers-from-goahave-a-119-hour-nightmare-on-rails (2 Mar. 2021).

Haokip, Thongkholal (2020). "From "Chinky" to "Coronavirus": Racism against Northeast Indians during the Covid-19 Pandemic." Asian Ethnicity 22/2, 353-373, https:// doi.org/10.1080/14631369.2020.1763161 (2 Mar. 2021).

Jaffrelot, Christopher (ed.) (2007). Hindu Nationalism: A Reader. Princeton: Princeton University Press.

Khongji, Phrangstone, Nongkynrih, Deigracia (2018). Labour Supply and Unemployment Projections for North East India (2011-2031). Arthshastra 7/6, 30-42. 
Levinas, Emanuel ([1974] 1998). Otherwise than Being, or Beyond Essence. Dordrecht: Kluwer Academic Publishers.

Lusome, R., Bhagat, B. (2020). Migration in Northeast India: Inflows, Outflows and Reverse Flows during Pandemic. Indian Journal of Labour Economics 63/1, 11251141, https://www.ncbi.nlm.nih.gov/pmc/articles/PMC7585351/ (2 Mar. 2021).

McDuie-Ra, Duncan (2012). Northeast Migrants in Delhi: Race, Refuge, and Retail. Amsterdam: Amsterdam University Press.

Parrott, Justin (2018). The Golden Rule in Islam: Ethics of Reciprocity in Islamic Traditions (unpublished Master's thesis). University of Wales.

Rahman, Mirza Lutfur (2020a). The Story of a Doubtful Citizen in Assam, 30 Aug., https:// www.youtube.com/watch?v=QFBYrtG2qiA (2 Mar. 2021).

Siddiqui, Mona (2015) Hospitality in Islam: Welcoming in God's Name. New Haven: Yale University Press.

Standing, Guy (2011). The Precariat: The New Dangerous Class. London: Bloomsbury Academic.

Tripathi, Sabyasachi (2016). Determinants of Employment and Unemployment Situation in India with Special Reference to North Eastern States of India, 20 May; last modified 26 Sept. 2019. MPRA Paper 71469, https://mpra.ub.uni-muenchen. de/71469/ (2 Mar. 2021).

Xaxa, Virginius, Debdulal, Saha, Rajdeep, Singha (eds.) (2019). Employment and Labour Market in North-East India: Interrogating Structural Changes. New Delhi: Routledge. 


\section{POVZETEK}

\section{MUSLIMANSKI PREKARIAT V ASSAMU: OKUŽBE, MIGRANTI IN COVID-19 Yasmin SAIKIA}

Članek obravnava stiske migrantskih muslimanskih smetarjev med popolnim zaprtjem javnega življenja v Indiji leta 2020. Ti »nevidni ljudje«, ki jih trenutna indijska vlada poniževalno označuje za gedha miya ('umazane Bangladešce') in jih obravnava kot nedržavljane, v indijskih mestih, daleč od domače pokrajine Assam, živijo tako rekoč iz rok v usta, čeprav je njihovo delo nujno za blagostanje celotne države. Njihove težave zaradi dela zunaj domačega Assama, kakor tudi ovire, s katerimi so se morali spopadati med poskusi vračanja v rodne vasi, so se zaradi družbenih, političnih in verskih predsodkov še stopnjevale.

Avtorica je življenje smetarjev iz skupnosti miya raziskala pred zaprtjem države, med njim in po njem, njena metodologija pa je temeljila tako na zgodovini kot etiki. Raziskovala je s pomočjo telefonskih intervjujev in klicev po aplikaciji Zoom, podatke o karantenskih zmogljivostih pa so ji posredovali državni uradniki in lokalni novinarji v pokrajini Assam. Po njenem so »ničvredna življenja« muslimanskih smetarjev dragocena že zato, ker imajo ti kot človeška bitja svoje dostojanstvo in si za svoje delo zaslužijo spoštovanje. Prijaznost posameznikov, ki so se med lockdownom odzvali njihovim klicem na pomoč in jih obravnavali kot človeška bitja, vzbuja upanje na drugačen odziv ljudi v kriznih časih.

Izkušnje smetarjev med pandemijo odražajo splošno usodo muslimanov v Indiji. Vlada se zanje ne meni in jih obravnava kot manjvredne, pred njimi pa si oči zatiska tudi javnost. Za avtorico je vsakdanji boj assamskih smetarjev za preživetje pravzaprav boj za preživetje muslimanske skupnosti v Indiji, ki je sicer vidna, nikakor pa ni videna. Pravo pot za ublažitev težav indijskih muslimanov avtorica vidi v zavzemanju civilne družbe zanje, študijo o smetarjih pa razume kot nekakšen temeljni kamen za začetek poti. 